Gramáticas de la (¿post?) violencia:

identidades, guerras, cuerpos y fronteras

\title{
Akroá-Gamella: territorial struggles and narratives of violence in the Baixada Maranhense
}

\author{
Caroline Leal ${ }^{1}$ \\ ' Universidade da Integração Internacional da Lusofonia Afro-Brasileira, \\ Faculdade de Antropologia, Ceará, Brasil
}

\begin{abstract}
The Akroá-Gamella people reside in the State of Maranhão, in the northeast region of Brazil. They began to experience broad visibility, on national and international levels, as victims of a genocidal action contrived by agribusiness sectors, following an event named "Movement for Peace" in April 2017. This article sets forth an ethnography of patterns of violence that serve to maintain power inequalities between indigenous peoples and political organisations that control work and private property in the Baixada Maranhense. The text begins with a brief historical overview of the territorialisation process set in motion by the Akroá-Gamella in the last decade, followed by an analytical description of the cartography of conflicts derived from this people's political insurgence. The text also focuses on implicit and objective contents in practices that sustain symbolic and physical violence from the Indians' perspective, emphasising struggles undertaken in defence of territory and the right to existence.
\end{abstract}

Keywords: Akroá-Gamella; territory; genocide; Baixada Maranhense; Brazil. 


\section{Akroá-Gamella: luta territorial e narrativas de violência na Baixada Maranhense}

\section{Resumo}

O povo Akroá-Gamella vive no estado do Maranhão, nordeste do Brasil, e passa a ter ampla visibilidade no cenário nacional e internacional como vítimas de um ação genocida planejada por setores do agronegócio durante evento denominado "Movimento pela Paz", em abril de 2017. Este artigo propõe uma etnografia dos padrões de violência que operam para a manutenção da desigualdade no poder dos indígenas em relação às organizações políticas que controlam o trabalho e a propriedade privada na Baixada Maranhense. $\mathrm{O}$ texto inicia com um breve histórico do processo de territorialização desencadeado pelos Akroá-Gamella na última década, seguido de uma descrição analítica da cartografia dos conflitos decorrentes da insurgência política deste povo. Focaliza ainda os conteúdos implícitos e de ordem objetiva nas práticas que sustentam as violências físicas e simbólicas a partir da perspectiva indígena, dando ênfase às lutas empreendidas na defesa do território e do direito a existir.

Palavras-chave: Akroá-Gamella; território; genocídio; Baixada Maranhense; Brasil. 


\section{Akroá-Gamella: territorial struggles and narratives of violence in the Baixada Maranhense}

Caroline Leal

\section{Introduction}

The Akroá-Gamella ${ }^{1}$ people are based in the State of Maranhão, a transition zone between the North and Northeast regions of the country, with an estimated population of 1.130 people (FUNAI 2015) ${ }^{2}$ spatially organised into six communities formed according to kinship criteria. Eleven ethnicities reside in this state, in 22 Indigenous Lands ${ }^{3}$, with a total population of 35.272 individuals (IBGE 2010).

The traditional disputed territory is home to not only the Gamella communities, but also other nonindigenous populational hubs, which, from the mid-twentieth century onwards, have illegally taken residence in the aforementioned lands. This occupation was only possible owing to the flux of colonisation that has seized ample areas under the pretext of regional productive development, based on fraud and the falsification of land-deeds - what is commonly known as "grilagem de terras" ["land grabbing"]. This disputed area encompasses three municipalities, Viana, Matinha and Peralva ${ }^{4}$, which are located in the microregion known as the Baixada Maranhense. The microregion extends for 18,ooo square kilometres of unique environments and includes a wealth of hydric resources, most notably the Mearim, Pindare and Pericumã rivers, which comprise the Northeast's largest series of lacustrine bays (Martins \& Oliveira 2011).

Paradoxically, the environmental wealth of this region is transformed into a vector for socio-economic contradictions, since it is not manifested in the quality of life of the general population. Current research shows that the Baixada Maranhense has low social indicators and high population vulnerability regarding access to public policies related to basic services, such as education, healthcare and sanitation (UFMA 2015). These structural deficits derive from the land-grabbing process: a powerful political mechanism - one among several used by the rural elite - to maximise land ownership and income concentration throughout the second half of the twentieth century. The practice of land grabbing and its inherent violence forms the basis of the establishment of a new model of land appropriation that extends to the present day (Costa 2006; Asselin 2009).

\footnotetext{
1 This ethnonym is a self-attribution referenced by two peoples who affirm the Akroá and Gamella are their historical ancestors. In the literature on the colonial period, they are cited both as enemies and as allies in relation to the "expeditions" in the sertões of the Piauí and Maranhão captaincies. (Apolinário 2005). Their oral history affirms that the present social formation stems from these two peoples, who resisted colonisation through being skilful in war strategies. Therefore, the conjoining of the Akroá and Gamella names expresses a connection between the past resistance movement and the present to conserve their collective territory, regardless of the fact that the origins of these ethnonyms are designations external to the group, since they derive as from colonial agents. Throughout the text, we will use both the compound name and Gamella, based on redaction criteria and in consideration of the fact that the latter form is the most commonly used by the Indians colloquially.

2 Census conducted for the Technical Qualification Report on the Akroá-Gamella's Territorial Demand, 2015.

3 In reference to Indigenous Lands with ongoing administrative regularisation procedures implemented by the official organ for Indian affairs, the National Indian Foundation (Fundação Nacional do Índio, FUNAI), an institution linked to the Ministry of Justice.

4 According to the 2010 census of the Brazilian Institute for Geography and Statistics (Instituto Brasileiro de Geografia e Estatística, IBGE), the population in each municipality is 49.496 in Viana, 21.885 in Matinha and 34.267 in Penalva.

5 Núcleo de Estudos e Pesquisas Ambientais (NEPA) [Centre for Environmental Studies and Research] of the Federal University of Maranhão (UFMA).
} 
Recent data offers parameters for analysing the contemporary effects of this historical process. The State of Maranhão occupies prominent positions in the national ranking of the occurrences of slave labour (Ministério Público do Trabalho 2015) ${ }^{6}$ and land conflicts. According to the last report on violence published by the Pastoral Commission of the Land (Comissão Pastoral da Terra, CPT) (2016)7, 194 land ownership conflicts have been recorded, as well as 13 deaths and over 31 thousand affected families. Violence against indigenous peoples continues to increase. In 2016, the number of homicides related to territorial disputes peaked at 12, surpassing indicators from previous years (CIMI 2017).

While remaining invisible to the State's selective gaze, the Akroá-Gamella, became tragically wellknown on April $30^{\text {th }}, 2017$, as the victims of an genocidal action by a group known as "Movimento pela Paz" ["Movement for Peace"]. The largest concentration of the movement originated in a settlement in the municipality of Viana, Maranhão, on the margins of MA-014, a road that goes several kilometres into the territory claimed by the people. The event, broadcast by local radio stations, was organised by the local agrarian elite, members of evangelical churches and members of both federal and municipal legislative powers linked to ruralist interests. Characterised by the Indians as an arbitrary attempt to silence their people's existence and later reported as "ethnocide" and a "massacre" by both national and international medias, the so-called "Movement for Peace" and its outcome in victims, entered the calendar of historical obliterations of Brazilian indigenous peoples' fundamental rights.

A group of 30 Akroá-Gamella Indians organised the retaking, carried out a few hours earlier, of an area of their traditional territory when they were ambushed and savagely attacked by approximately 250 demonstrators armed with knives and firearms. The mob headed for the retaken area once the speeches of the "Movement for Peace" speakers had ended. The Gamella were shot and beaten, and not even the women and children were spared. Two Indians had their knees sliced open and hands cut off - details common to this kind of violence in the State of Maranhão. The Military Police garrison that proceeded to the location stood inert as the episode unfolded. The brutal attack, from which the Gamella were in no condition to defend themselves, achieved worldwide repercussion.

The Brazilian State and the government of the State of Maranhão could no longer evade recognition of this violent historical conflict involving the Akroá-Gamella, even though, as Judith Butler has stated, "to avow injurability does not in any way guarantee a politics of non-violence"(2017:250). The fact is that the State implemented an administrative procedure to initiate the process of regularisation of the Indigenous Land ${ }^{9}$. Certainly, there are belated decisions to be made, particularly regarding the powers of the Executive and Judiciary, given that ongoing investigations have failed to prove conclusive regarding who was responsible for inciting the attack and who the perpetrators of the violence were. However, the beginning of the work of demarcation creates possibilities for these people to collectively overcome a painful chapter in their history, which is interwoven by permanent strategies of territorial defence.

This article proposes an ethnography of the patterns of violence that operate to maintain inequalities of power between the Indians and the political organisations that control work and private property in the Baixada Maranhense. Why are violations in the lives of these people allowed? Why are they not worthy of

\footnotetext{
6 For more detailed information, see <http:|/observatorioescravo.mpt.mp.br/>. Accessed in December 2017.

7 Conflicts entail several modalities of violence, such as murder attempts, death threats, arrests, attacks, generally directed towards leaders of agrarian social movements. The report shows that Maranhão surpasses states nationally known for agrarian conflict, such as Rondônia (172 cases), Bahia (164 cases), Pará (143 cases) and Minas Gerais (116 cases).

8 Data gathered by the Indigenous Missionary Council (Conselho Indigenista Missionário, CIMI) (2017) shows the murder of six Guajajara, five Tenetehar/ Guajajara from the Arariboia Indigenous Land, and one Gamella. About a dozen reports on death threats, mainly among the Ka'apor and the Gamella and, among other modalities of violence, there are 14 additional reports from indigenous lands all over the state relative to territory (invasions with intent to claim the land and illegal exploitation of natural resources).

9 Creation of the multidisciplinary Technical Group through Decree no. 1.171 of the Presidency of the National Indian Foundation (FUNAI), dated November $10^{\text {th }} 2017$, published in the Official Gazette of the Union, no. 218, November $14^{\text {th }} 2017$, Section 2, p.35.
} 
state protection? How do we comprehend this stark increase in violence against the Gamella? With these questions in mind, we presume that there a selective power mechanism exists in which vulnerability, pain and death become effective resources to weaken and exert control over social belonging, the land and claims to collective rights.

Supported by the literature on Brazilian anthropology concerning indigenous peoples - with an analytical focus that articulates categories such as territory, history and resistance - and the theoretical perspective of the coloniality of power, formulated by Peruvian sociologist Anibal Quijano, this article analyses the characteristics and implications of such material and symbolic violence to reflect on continuities between colonial ideology and its contemporary manifestations. In times of neoliberal multiculturalism, which propagates the recognition of cultural differences even if only to appropriate them according to the logic of the global market, in Brazil, indigenous peoples witness, feel and resist the reactualisation of genocidal values and practices. The case of the Akroá-Gamella is highlighted within this context.

\section{Territorialisation Process}

The regrouping of the Gamella as an indigenous people in the last decade is more easily understood when considering the territorialisation process ${ }^{10}$ that has been taking place since 2012. The political context was directly related to the process of land grabbing within the territory, initiated in the 196os, which engendered the conditions for the consolidation of more complex power relations in the daily lives of the communities. The increasing presence of private projects, such as the felling of extractive areas to cultivate grasslands and the construction of fish-tanks in water springs, accelerated the collective decision to formulate a project for retaking the traditional territory. In the words of the indigenous leaders, "to fight for the territory so the people can live freely and reforest sacred nature, to ensure the freedom of the waters, the guarimã , the babaçu, the buriti, the juçara" (Leadership Council 2017)"'.

The previous movement for official recognition, active in the 1970 and 80 , yielded no results, since at that time, the political power of the indigenous movement in relation to the State was still in the making. The period following the promulgation of the Federal Constitution of 1988 bespoke a significant shift in this scenario, up to then characterised by categorical disadvantage. In several regions of the country, indigenous peoples began mobilising, triggering processes of ethical emergence, particularly in the Northeast. In the field of indigenous ethnology, there is a large collection of research depicting territorial disputes as vectors of ethnic mobilisation on the part of peoples deemed extinct in official literature and documentation ${ }^{12}$.

Since the nineteenth century, the Gamella people have continuously witnessed the looting and environmental degradation of their territory. The elite view this as development, but from the perspective of the Indians, who have a much more intimate relationship with the environment, it is understood as violence, exploitation and the silencing of nature. For this people, it is about uncontrolled capitalist exploitation and the irresponsible use of high-impact technologies that render biological reproduction unfeasible. The kind of conflict that is established between these two points of view lies in the impossibility

\footnotetext{
10 The concept, approached according to João Pacheco de Oliveira, is a process of social reorganisation that implies: 1) the creation of a new sociocultural unit by establishing a differentiating ethnical identity; 2) the constitution of specialised political mechanisms; 3) the redefining of social control over environmental resources; 4) the re-elaboration of culture and relations with the past (OLIVEIRA 1999:20).

11 In compliance with requests from the Gamella Leadership Council, interviewees will not be identified directly by name, in order to preserve them, given their current situation of extreme vulnerability. Statements used in this text have been recorded in collective meetings with leaders from the council, during fieldwork in the indigenous territory, in March 2017.

12 Emphasis on investigations conducted by the projects "Levantamento de Terras Indígenas no Estado da Bahia [Mapping of Indigenous Territory in the State of Bahia” (PINEB/UFBA) and "Ethnical Frontiers, Territory and Cultural Tradition” (Museu Nacional/UFRJ).
} 
of the coexistence of such antagonistic projects. The life the Gamella yearn for in the reclaimed territory, in all its senses - epistemological, spiritual, economic, social, cultural, cosmological -, cannot be achieved under the subjugation of agribusiness in the Baixada Maranhense. Amid the innumerable contingent tensions, I'd like to highlight the most emblematic cases that help characterise the cartography of conflicts, as well as the reaction of part of the Gamella communities to review the historical course in the face of threats to the future of the people and the territory itself.

First, the Gamella territory was expropriated during the twentieth century due to land grabs - one of the most effective illegal mechanisms of domination and property concentration in rural Brazil, particularly in the Legal Amazon area. In the 196os, there was a notary fraud involving land deeds pertaining to the area known locally as Indian Land (Andrade 2008). Ever since, the buying and selling of indigenous territory has intensified. The consequences of this cannot be reduced to the mere loss of land, because land grabbing is a phenomenon that demands physical violence in order to become effective, as has been confirmed in some situations. Indigenous leaders who denounced the situation became the victims of hired thugs, and the memory of such violence transformed into a continual threat still felt today. There is also reference to the emergence of internal conflicts, since indigenous families sold plots of land adhering to the promises of economic emancipation, which then favoured the occupation of the territory by farmers and small peasants. Thus, a complex network of inter-social relations was instituted.

Maristela Andrade's (2008) research informs us that the 1970s is marked by the advance of farmers in the territory. Legal actions initiated by the Gamella yielded nothing, since Brazil was going through a military dictatorship which defended the development of the interior, together with the tutelage of indigenous peoples. During the 1980s, the Gamella gained the support and the advertising services of pastoral organisations and began to politically engage with the Rural Workers' Union (Sindicato de Trabalhadores Rurais) in pursuit of institutional conditions to reverse, or at least hinder, the advance of land-grabbing. This search for a solution with farm workers was primarily due to the denial of assistance by the National Indian Foundation (FUNAI). The indigenist organ was actually summoned in 1982, but failed to institutionalise the process of indigenous land recognition.

In their oral history, the last decade of the twentieth century are referred to as a period of protagonism among Gamella women concerning their actions in retaking the territory. As stated by one of the leaders of the movimento de quebradeira de coco babaçu [babaçu coconut breaker movement]: "the women use their very bodies to defend our way of life". This experience of struggle embodied in women is evidenced in a statement given by a Gamella woman who actively took part in the retakings of the period:

It was a women's struggle against Roseana Sarney, though as squatters and not as Indians, because, at the time, FUNAI did not accept our land claim. It was the biggest farm around here and it was horribly devastated to raise cattle. Everything was ruined! The buritizal, the guarimã, the fibre used in our craftwork, not to mention polluting the river. Here, Gamella women live off the extraction of fibre and the babaçu coconut, as well as the juçara. We couldn't stand to see all that nature being destroyed, the hired hands wouldn't let us in to collect fibres and fruit. So, we gathered all the women and headed over there, the hired hands thought the men were coming, but it was the women. Them on one side, us on the other. (Gamella elder 2017)

The felling of native forests for the expansion of grasslands destined for cattle and buffalo farming constitute the second aspect of rising conflict. The invasions of areas closer to lakes and rivers are directly related to reports of fires and deforestation affecting plant species of extreme importance for the spiritual and economic practices of the Gamella people. Currently, Maranhão's Energy Company is also the target of 
reports on the part of Indians due to the devastation of sacred woods and environmental crimes perpetrated to install energy transmission lines across the territory, without prior consultation of the people, as determined by Convention 169 of the International Labour Organisation (CIMI 2017).

In light of these offensives, in 2014, the Akroá-Gamella ${ }^{13}$ organised their first assembly in the village of Taquaritiua, during which they declare themselves an indigenous people and proceed to demand from the State recognition of their territorial rights and access to public policies specific to indigenous peoples. For the municipality of Viana and the surrounding region, the Gamella insurgence proved an unpleasant experience, since it questioned dominant structures and brought with it the political power of the indigenous movement. The territory, up to that moment situated within an agrarian system controlled by the local elite, became a target for land retakings and was partly recuperated and integrated into the people's autonomous governance.

The tensions established, therefore, have to do with the question of recognition of the Gamella as an indigenous people and territorial conduct framed by knowledges, cosmologies, historicity and collective ethics that diverged from the territorial ideology of the nation-state, which is geared towards the structural systemic interests of capital accumulation. Consequently, questioning the identity of the Akroá-Gamella takes on strategic characteristics of delegitimisation of the struggle for land. Amid the region's population, racist judgement is disseminated according to which being a Gamella is a euphemism for "land thief". Numerous inhabitants developed a mannerism of negating the local indigenous presence, which, in itself, contradicts the fact that Taquaritiua ${ }^{14}$ is often referred to by them as "Indian land" and their own acknowledgement of kinship ties with these Taquaritiua Indians. These abiding interactions, however, do not prevent acts of excessive hostility against the Gamella.

\section{Racialisation of difference and the question of recognition}

According to Judith Butler's (2017) perspective, the implications of acts of recognition must be understood as a dynamic and historical field, since it is primarily about discussing how certain notions of people and social groups determine the condition of being recognised. It implies thinking how recognition of the other is determined by a normative ideal and "how such norms operate to produce certain subjects as recognizable persons and to make others decidedly more difficult to recognize" (2017:20. emphasis in the original). In our case, what norms determine the indigenous condition?

The good and bad savages of European chroniclers are not outmoded visions. On the contrary, this is an imaginary that is constantly renewed and continually produced by Maranhão's political and agrarian elite to foment a debate that involves notions of "people" and "territory" limited by the nation-state. As argued by theorists affiliated with the coloniality of power, modernity/coloniality is a duo that functions by (re) accommodating itself to local structures in different ways, based on power patterns instituted since the time of colonisation.

The logic of coloniality in force in the Baixada Maranhense has an effective meaning and is translated in the racism and racialisation of sociocultural differences as founding elements of dominance and violence against the Indians, the quilombolas and women coconut breakers. Aníbal Quijano theorises on an idea of race as a historical movement in order to establish "a new system of social dominance and a new system of social exploitation" (2005:17). It is the intentional production of a violence that operates both in the material

13 According to the minutes, human rights organisations of national reach, such as the Pastoral Commission of the Land (CPT) and the Indigenous Missionary Council (CIMI) took part in this assembly, together with other indigenous peoples, such as the Krenyê, Krepum Kateje and the Tremembé.

14 Taquaritiua is a historically important village for the Gamella, because it represents a place of the people's resistance since the late nineteenth century. 
and subjective realms. Subjectivities are affected, relocated, subsumed to this pattern of power that Santiago Castro-Gomez (2005) calls epistemic violence, since it is about power/knowledge devices that serve as starting points for the construction of negative representations.

From this analytical perspective, we understand that racism is a type of hierarchisation that operates, in this context, to invalidate the notion of indigenous peoples of power - a notion that, in turn, is linked to the constitutional right to lands they have traditionally occupied (article 231 of the 1988 Federal Constitution).

In the case of the Akroá-Gamella, the racism that is perpetrated distorts their historical situation of lengthy contact with Brazilian society and "mixtures" ${ }^{15}$ with black people and individuals born in the Sertão in order to disqualify their claims of being indigenous. Negative representations borrow from evolutionist thought the stereotype of the naked Indian, phenotypically alike and speakers of a "dialect". An example of this evolutionary thought finds agreement in institutional state racism, which imposes itself on the daily lives of this people; the system of inequality employed is the recurrent denial of Gamella existence.

In the federal executive branch, one fact that had broad repercussions in the media was a statement from then Minister of Justice, Osmar Serraglio (PMDB-PR), a member of the rural caucus, on the days following the April $30^{\text {th }}$ massacre. Serraglio referred to the Gamella as "alleged Indians". The negative repercussion of the official statement embarrassed the Ministry of Justice. The solution drummed up by the Minister's cabinet members, in their statement, was to substitute "alleged Indians" with the generic "agrarian conflict" ${ }^{\prime \prime}$, thus maintaining their lack of acknowledgement of the indigenous character in the scenario of this episode of unquestionable violence.

Within the judicial system, according to the complaint registered in the Report on Violence against Indigenous Peoples (CIMI 2017), the state district judge granted an eviction injunction against the Indians on the grounds that "they were no longer forest people". Despite the fact that national and international legislation (Convention 169 of the OIT) does not allow the State to determine who is indigenous or not, it is important to note the strategy of the State Judicial Power in handling Gamella matters. In Brazil, indigenous issues are within the jurisdiction of the federal judiciary. Thus, the state judiciary has no bearing on such matters, the repossession of land, unless the fact that the case deals with indigenous people is disregarded.

In the legislative branch, the federal congressman from Maranhão, Aluísio Mendes (PTN/Podemos), together with allied councillors, has been indicted for his direct links to the public manifestation that led the Viana population to attack the Akroá-Gamella ${ }^{17}$. The congressman's participation in a programme on a local radio, Maracu $\mathrm{AM}^{18}$ only days before the genocidal act, also reinforces the racist stance and incitement of hate that engendered a general state of warfare against the Indians, working from the idea that they were the enemies of progress and of small landowners.

\footnotetext{
15 The term "mixtures", used here, situates the theoretical perspective developed by some anthropologists who devote themselves to studies on indigenous peoples of the Northeast region, such as DANTAS et al. 1992 and OLIVEIRA 1999. These authors theorise on the construction of the object "Northeastern Indians" based on an ethnology of the so-called "mixed Indians" (OLIVEIRA 1999:11). Such studies proceed from the problematisation of stigmatised idioms used to refer to peoples from the region, such as "mixed Indians", as opposed to "pure Indians". Thus, the use of "mixtures" testifies to the distorted ideological fabrication that lies behind the name and underpins the historical situation of several indigenous peoples in Brazil.

16 The statement has since been taken down from the official website, but public repercussion will not let the event slide. See: <www.brasil247.com/pt/247/ brasil/293219/Serraglio-chama-índios-atacados-de-“supostos-indígenas”.htm〉; 〈http://www.cimi.org.br/pub/Porantim/2017/Porantim395_Mai2017.pdf〉; 〈http://www.gazetadopovo.com.br/politica/republica/5-polemicas-que-marcaram-osmar-serraglio-no-ministerio-da-justica-atwimr8hzg3ozlu22z6s4dltg〉.

17 Among news pieces detailing the congressman's participation, we highlight the following, featured in Le Monde Diplomatique (edition 122) <http:// diplomatique.org.br/novo-massacre-indigena-no-maranhao>. Accessed in September 2017.

18 Leased by one of the farmers who had their lands repossessed by the Gamella on August 2016, whose ownership reintegration case has yet to go on trial. This radio broadcast can be accessed at the following address: $\langle$ https://www.youtube.com/watch?v=-AkvCfPEgH4 >.
} 
During the "Manifestation for Peace", on stage, the congressman made reference to "pseudo-Indians" and summoned demonstrators to act with the following speech: "Here, no one's blood is cheap. No one is going to tolerate this provocation any longer" ${ }^{\prime 19}$. According to Gamella narratives on the massacre, part of the crowd present at the act went on to ambush the Indians.

Another mechanism of institutional power to consign indigenous people to the zone of non-being operates through the city's registry offices, which refuse to register children under their indigenous names. ${ }^{20}$ The use of slander against the Gamella, the accusations of land-theft, is propagated with ample creativity, rife with appended offenses. The effect of these attacks is a wounded, mortified collective morale. At all times, in the presence of outside interlocutors, they explain: “We don't want anything that isn't ours. We're not thieves". The Gamella are also commonly and pejoratively compared to animals that suggest filth and bestiality. In this regard, I am reminded of an analysis by Fanon: "in fact, the terms the settler uses when he mentions the native are zoological terms" (2010:59).

A sociological comprehension of this generalised racism implies establishing a historical-conceptual relationship between the experience of colonialism, coloniality and the production of colonial difference in the region studied. Regarding the notion of colonial difference, Quijano (2005) explains that the coding of differences between colonisers and colonised became decisive in determining the historical process and the intentional permanence of such differences as a pronounced domination mechanism.

Why must the indigenous being, the Akroá-Gamella being, undergo the scrutiny of those who seek to dominate? I believe an understanding of this is possible once we reflect on Fanon's statement that "any ontology is made impossible in a colonized and acculturated society" (2008:103). Fanonian critique draws our attention to the fact that the Being cannot be comprehended if we ignore the metaphysical, historical, social and political existence of the colonised subject and admonishes that, between the body of the colonised subject and the world, an effective dialectics is established.

Empirical experience, aided by the ability to both see and hear ethnographically, makes it possible for me to perceive that the road to the insurgent Gamella movement is constructed from a very strategic place: historical memory. It is the collective memory of violence suffered since the colonising process that has compelled them to want to remain a people. More than a desire to publicly show themselves as Indians, of defending their own culture, they want to resume something that has been violently interrupted, that is, their condition as a people. As Rita Segato (2012:25) questions, "what is a people? A people is a project to be history".

Breaking with the imposed order of silence and submission to local farmers and resuming a political process of ethnical identification has meant reclaiming collective ownership of the territory and their self-determination, through the constitution of an autonomous social organisation. It has also meant decolonising relations of subjugation of Being and Power by transgressing the condition of a diffuse, subaltern population among the locals in order to declare themselves an autonomous people, even when threatened with political, social and physical violence. The Gamella people disobey and destabilise imposed patterns of power, as analysis shows in one of the texts authored by the Gamella leaders, in which we find an interpretation of State violence perpetrated against the people even before the massacre:

\footnotetext{
19 Speech excerpted from news stories; emphasis on a news item titled "Eles são mesmo índios?, a pergunta por trás do ataque aos Gamella” ["Are they really Indians? The question behind the attacks on the Gamella"], published on Repórter Brasil on June, 2017. Available at <http://www.ihu.unisinos.br/78noticias/569124-eles-sao-mesmo-indios-a-pergunta-por-tras-do-ataque-aos-gamela . Accessed in December 2017.

20 The right to a certificate for an indigenous birth at the Civil Registry of Individuals is ensured by the Joint Resolution of the National Council for Justice (CNJ) and the Public Ministry's National Council (CNMP), no. 3, 2012.
} 
Good afternoon! Today we march, as our ancestors did, over the city of Viana, MA, in defence of the right to Existence and to our Territory. We have been summoned by the chief of the civil police to appear at the police station in order to testify on the cutting of barbed wire fences put up by a farmer-land grabber. The fences were being put up on the path to one of our villages. We then proceeded to the Viana County Hall to discuss the matter of the Registry of Indigenous Births. The notary of the registry office of Viana's $2^{\text {nd }}$ Office has been refusing to fulfil Resolution no. 3/2012 from the National Council for Justice and the Public Ministry's National Council, which addresses the matter. We have a right to a name in our language, to have our ethnicities as last surnames and the inclusion of the parents' village on the Birth Certificate. We would like to seize the opportunity also to protest the closing of our only school for reasons not presented by the Municipal Secretary of Education. On March $31^{\text {st }}$, the secretary of education is on record stating classes would begin on March $3^{\text {rd }}$, which did not occur. Our rights are non-negotiable. Education is a right, but it has to be on our terms! Today, we decided to go to the State's Public Ministry to register the accusation. On the hearing held at the civil police station, there were about 150 of us Indians -, against the police chief's wishes, we all occupied the internal premises of the police station. There were contradictions between police officers. One of them said he had no idea this was an indigenous community, which was kindly rebuffed by the other officer. We sang, we sang and left, leaving farmers and police officers behind. However, a Gamella is a Gamella. A fence that was penning the bacurizeiro and the piquizeiro was taken down, and now, forever free, they show their appreciation by giving us delightful shade to soften the heat of the day. (Gamella Leadership Council 2017) ${ }^{21}$

Collective narratives centred on recent political insurgency often resort to words such as territory, freedom, nature. In the arid context of the Baixada Maranhense, these reveal epistemic contents that gain new dimensions when analysed from the perspective of the Gamella's colonial difference. Despite the inequality in power and attempts at delocalisation and deterritorialisation throughout the twentieth century, collective memory informs the maintenance of numerous practices that are local, embodied and rife with significance for the social existence and daily elaboration of Akroá-Gamella identity. It is in this sense that I place the process geared towards territorial reconquest, causing it to emerge as indigenous and in defence of an insurgent ethical-political project as a strategy for overcoming a condition of historical subjugation.

The radicalisation of this people's struggle has taken the form of "retakings", an organisational practice with a broad capacity for internal mobilisation and external partnerships in the field of human rights fields. Between 2015 and 2017, the Gamella retook five areas, following criteria that determined regions of the territory that were most vulnerable with regard to environmental degradation perpetrated by others. The retakings have yielded political results that have exposed the intimate relations between the coloniality of power, the dehumanisation of Indians and the proliferation of genocidal values, particularly against - to it is worth emphasising - subaltern social groups, such as Indians, quilombolas and babaçu coconut breakers, whose historical territories are a threat to privatising, homogenising forms of territorial organisation (Little 2002).

As I will demonstrate, actions against the struggle for autonomy in the Baixada Maranhense are translated into a re-actualisation of the "just wars", meaning they are deemed to be morally acceptable for the standards of racist thought, and economically necessary for colonial capitalism, which persists in the innermost regions of this Brazilian state.

21 This letter is unpublished, since it was written by the leadership to share with organisations offering support and advice on the course of their resistance strategies. My position as a researcher allowed me access to this document on April 6, 2017. 


\section{Scenes of April: a genocidal movement for peace}

The "Movement for Peace" is interpreted in this article from the perspective of the Akroá-Gamella people and the characterisation of their contemporary process of territorialisation. Not as a situational genocidal act, but as processual, premeditated and justified in accordance to a salvationist mission with regard to private property in the Baixada Maranhense,

We were in the middle of a retaking and when we saw the demonstrators coming, some of us managed to run while others didn't. I was one of those who couldn't escape because I was caught off guard by a shot in the back and soon after someone came over to slice me up, and I recognised it was one of the gunmen hired by a farmer who has lands on our territory. I looked around and saw a relative also being cut up and he couldn't move due to the cuts on his legs and hands. At that moment, I was taken over by an Encantado [spiritual entity] and lost my eyesight; I could hear everything but I couldn't see, and my Encantados told me I was going to be rescued and I shouldn't worry. They didn't try to finish me off because they thought I was already dead. Early in the evening, three policemen came by and one of them asked me whether I knew why I was going through all that and I just answered that I wanted to be rescued. Then, another man from the village came and told me: if we had found you far from the policemen, we would have set you on fire. But, since I am a believer in Our Father and the Encantados, in the fact that they protect our people everyday, it so happened that I escaped alive. What the white man does to the Gamella people and other relations also isn't fair, because the Encantados live where we live, in the woods, which are being destroyed (Gamella Leadership 2017)22

The above statement reveals an important aspect for this analysis, the fact that there were gunmen infiltrated among the demonstrators incited against the Gamella retaking, and suggests that they were aware who the principal leaderships were, since these were the Indians most hunted and brutalised. According to the bulletin of the hearing at the Inter-American Commission on Human Rights (IACHR) ${ }^{23}$, the State knew that gunmen were present in the area:

Episodes of invasion in Gamella villages by armed men and gunshots fired against the Indians were becoming commonplace and have been widely reported. In December 2015, an attack had already taken place involving gunshots against the Gamella. On August 2016, three armed men, claiming to be police officers, invaded a retaken Gamella region, and, on another occasion, armed men on two motorcycles fired shots at the Indians. The people reported to Brazilian State authorities that the farmers were organising a large indigenous massacre. However, the State failed to properly investigate these prior violent incidents, which contributed to the perpetuation of the tense situation (IACHR 2017:26)

Another piece of information which further delineates this cartography of violence and reveals the multiplicity of agents involved is related to the Military Police:

The major states that nothing could be done because all available officers - four officers plus a police vehicle - were scheduled to cover an event that was taking place in town: precisely the "Manifestation for Peace". At any rate, the car proceeded to the region retaken by the Gamella. "The police did go there, maybe four of them.

\footnotetext{
22 Interview conducted on November 1oth, 2017, during the occupation of FUNAI in São Luis, the state capital of Maranhão, integrally granted by the Indigenous Missionary Counsel and still unpublished.

23 Public Hearing: Human Rights Situation of Indigenous Peoples in Brazil, $165^{\text {th }}$ Period of Sessions of October $23^{\text {rd }}$ 2017, Montevideo - Uruguay. IACHR is a leading autonomous organ and of the Organization of American States (OAS). Report available at: <http://www.dpu.def.br/images/stories/pdf_noticias/2017/ informe_cidh_indigenas.pdf>. Accessed in November, 2017.
} 
But not to talk to us. They came in, and had a word with the caretaker, whispering”, says Maria das Dores Gabão Gamela. The Indians recount that no sooner had the police left their place at the farm's entrance than the attackers gathered together. ${ }^{24}$

In the above news item, it is evident that the Military Police were present at the site of the massacre not long before the arrival of the mob - but did not inform the Indians of the dangers they were up against. For all intents and purposes, the Military Police Chief sought to exempt the corporation, justifying his inability to prevent the violence on the fact his personnel had been reduced to four officers, who were providing public safety at the widely publicised, aforementioned "Movement for Peace".

It seems paradoxical to me that this "Movement for Peace" would attract the institutional attention of the Military Police in its duty to secure public safety and order, as well as involving other State representatives, only to end up in a massacre. It so happens that the image of a raging mob bearing firearms, stones, sticks and knives, acting against a small group with no power to defend themselves from this type of violence, could compose the scenario for a faceless revolt against yet another "crime" perpetrated by the "land thieves". Conveniently allied with this narrative are repeated calumnies against the Indians. However, from details of the Akroá-Gamella's accusations, it is possible to discern that a premeditated inter-institutional articulation was taking place.

The Gamella narratives and news reports ${ }^{25}$ that circulated widely after the episode account for the fact that the discourse of political leaders at the movement's rally continually reference to a protest of "good people", "orderly folk" that "had never seen Indians in Viana and the surrounding region", and therefore could not accept "invaders on their lands". Ideological contents are explicit in the fabrication of an alterity that is dangerous and threatening to social order, as explained by João Pacheco de Oliveira,

Violence accompanied by acts of "conversion" (the "descimentos", "rescue brigades", "just wars") can only be minimised and forgotten because it follows - narratively - accounts of anthropophagy, prisoners destined for death, attacks, the death of settlers and the description of the martyrdom of missionaries. To be forgotten, genocide must be depicted as a simple, warranted reaction to acts of unspeakable, unexplained evil that legitimates the hypothesis of the evil nature of those autochthonous populations, who thus had to be defeated and subjugated, so they could then be domesticated and transformed. (Oliveira 2016: 19)

April $30^{\text {th }}, 2017$, was characterised as the height of the climate of war established since the assembly of self-declaration by the Gamella, but it cannot be understood in isolation. The dynamics that were active prior to the genocidal attack constitute descriptive elements of a pattern of power that operates on the same logic of domination of past centuries: hired gunmen, land deed fraud, dehumanisation and denial of indigenous identity as recourses for the interdiction of social territories. These are contemporary forms that subjugate life to the power of death, and death may take on several forms, whether in its material dimension or in an apparently more "indulgent" guise, which result in the destruction of a culture (Mbembe 2016).

I base my argument on the studies of Monica Espinosa (2007) on patterns of violence against the indigenous peoples of Colombia. The author broadens the concept of genocide by linking it to the racialisation of difference and, consequently, an act of elimination directed at the existence of a people and the silencing of its cosmology, its social world:

\footnotetext{
24 Excerpt from the news story featured in Le Monde Diplomatique Brasil (edition 122), on August 7th. Available at: <http://diplomatique.org.br/novomassacre-indigena-no-maranhao $>$. Accessed in September 2017.

25 The same sources indicated throughout the article.
} 
Genocide involves different physical strategies, such as massacre, mutilation, deprivation of a way of life, territorial invasion and slavery; biological strategies that include the separation of families, sterilisation, displacement and forced marches, exposure to illness, the murder of children and pregnant women; and, lastly, cultural strategies, such as the depredation of historical heritage, the chain of leadership and authority, the denial of legal rights, the prohibition of languages, oppression and demoralisation. The denial of memory is perhaps one of the most extreme forms of symbolic violence. The victims are forced to leave the human order, and are condemned to live in a place of non-memory and non-existence. (Espinosa 2007:274).

Even though there is the criticism of Manichean analyses in the field of anthropology, we cannot discard Fanon's statement (2010:62) in The Wretched of the Earth that the colonial context is characterised by a dichotomy between the zone of being and the zone of nonbeing. The insults heaped upon Gamella existence attest to this Manicheism, better put by Fanon (2010:59) when he said, "at times this Manicheism goes to its logical conclusion and dehumanizes the native, or to speak plainly, it turns him into an animal". This experience prompts us to re-examine the logic of violence in the construction of senses of otherisation that are designed to trigger war and to perceive how the type of manifestation of power that exerts control over life and death is materialised.

The maintenance of colonial difference for the Gamella does not (hinge) depend on random criteria. The context of the production of hate speech against this indigenous people is essentially political, based on a hegemonic interest in protecting private property in the Baixada Maranhense. Thus, arbitrating on the identity of a people necessarily implicates the interests of the arbitrator(s), or as the anthropologist Manuela Carneiro da Cunha (1987) said in another context, the idea of legitimation in a class-divided society presupposes that legitimating ideas favour class interests.

Maranhão is a state of historical struggles for the indigenous movement. The retaking of land is one of its main strategies, that is to say, conservative political and economic sectors are not unaware of the material consequences of this people's struggle: retaking and/or conservation of their traditional territories and the ensuing decolonisation of power relations. Since the first half of the twentieth century, the anthropological literature demonstrates how ethnic groups are indeed effective forms of cultural and sociopolitical organisation for reclaiming and conserving their territorial spaces.

Violence against indigenous peoples in the interior of Maranhão shows the close association between a colonial past and the current hegemonic thought:

The transformation of an autochthonous population, previously free and autonomous, into one that is subaltern, an indissociably violent and arbitrary process, responded to the dominant economic interests, such as the appropriation of land and the acquisition of labour, articulated with the consolidation of the ruling class and a structure of government. It was never done without a genocidal process - euphemistically termed "pacification" - that corresponded to the fabrication of a permanent state of warfare which, in practice, justified the complete denial of any rights to the autochthonous population. (Oliveira 2016:17)

The preservation of a state of war in the context of the Gamella, as it is referred to by Oliveira in the above quotation, gains contemporary features in the absence of protective measures from public authorities, for instance. The State's inertia is intentional and tends to shift its responsibility as co-author in the crimes to that of mere spectator. It so happens that the events of April $30^{\text {th }}$ had worldwide repercussions and the Inter-American Commission for Human Rights proceeded to formally address the State in the following terms: 
This case is evidence of the State's utter inoperability when faced with a premeditated attempt at genocide by farmers, politicians and evangelical groups. The organisation of this attack had already been reported by the indigenous people over three years before, without the State adopting measures to protect the Indians to any degree. [...] The people reported to Brazilian State authorities that the farmers were organising a large indigenous massacre. However, the State failed to properly investigate any of these prior violent incidents, which contributed to the perpetuation of the tense situation (IACHR 2017:26)

The current situation remains unstable and insecure: the possibility of new attacks has been reported within the strategies of publicizing the conflict, as confirmed in the bulletins of the Inter-American Court:

There have been recent reports that, in one of the town's settlements, the same farmers and politicians -who should have already been at least indicted for their participation in the April $30^{\text {th }}$ massacre - are again articulating a new genocidal attempt, this time with gunmen hired from local municipalities and armed training of other people in the town to attack the Akroá-Gamella indigenous people (2017:29)

Lastly, it is pertinent to reflect on the interpretation of the world that the Gamella defend in their relationships with the territory, with nature and with that part of the surrounding society that feels so bothered and threatened as to promote acts of extreme violence. When asked why they carry out the retaking of land, in the conception of the Leadership Council (2017):

This is fundamental to free the land and for us to feel free. It is a necessary act, for us to take down the fence. A fence is a violence that destroys relationships not only between people and the forest, the woods, the water, it also destroys relationships among people [...]. We're reforesting, planting... all the retakings free the babaçus. They also serve women who are not active in the retakings, which is a very local thing. We don't let anyone go hungry or be in need. One day everyone, men and women, will understand what we are doing and support us. When there is coconut, and juçara, we have everything. We are not that miserable. We have enough to eat without having to go into town, to the supermarket to buy bad food. We have smallholdings, we raise chickens, there are fruits... we're consuming city junk because we don't have a space of our own. That's changing, though, and it seems to bother a lot of people. We have an orchard here, even if gunmen come after us.

\section{The Struggle in Perspective}

The organisational dynamics of these Indians have a long historical trajectory. However, my approach focuses on those that played a prominent role in more recent territorialisation processes, set in motion from August 2014 onwards. The observation of these dynamics enabled the identification of two courses of action, one internal and the other external, that are interrelated.

The course that is internally constructed passes through paths of secrecy and sacredness, and therefore, it is only approachable by virtue of that which we are allowed to know. These are the transmission of knowledge and the history of resistance through orality; the resumption of spirituality in relation to the Encantados; and socio-political reorganisation. Processes that may be perceived as important dimensions of knowledge, being and power. Strategies pertaining to the external course include permanent articulation with human rights organisations, researchers, universities and social movements. In this field, they formally address the State repeatedly to report violations and demand public policies specific to indigenous people, such as health and education.

Oral history updates the collective memory of the territory as being the "land of the Indians" and the narratives of these elders, men and women, have enabled young leaders to become acquainted with the process of the social formation of the territory and the several strategic modalities used by previous 
generations, so that the people could remain in their place to this day. The contents present in orality are converted into recourses of legitimacy regarding traditional modes of occupation, which connects periods of occupation to particular forms of social relations with and within the territory.

The values that govern community life are captured in the narratives and orient conceptions of sociopolitical organisation, as was explained to me:

"We have no chieftain or medicine man, our political organisation is collective, we have envisioned it as a counsel because this is more representative and responsibilities are allocated more fairly. If there's only one representative of the people, things get centred on that individual and leadership may turn into privilege. We don't like privilege, it's not one of the people's strengths." (Gamella Leadership Counsel 2017)

The Leadership Council acts on collective deliberations made during gatherings and community assemblies. The court has been responsible for arranging legal and administrative reports on violations directly affecting the group. While denial of indigenous identity persists in local and official discourse, the Counsel has opted to end the silence and uses written, documented records to make their presence known in the indigenous scene. In doing so, the Gamella have undertaken volumes of claims and reports by means of official letters, reports, statements to the Office of the Public Defender addressed to FUNAI, to the Federal Public Prosecutor and to Federal and State public administrative organs ${ }^{26}$. After the April $30^{\text {th }}$ incident, they appealed to international human rights organs.

The first documents were sent to the official indigenist state organ, FUNAI, requiring the official recognition and commencement of the land regularisation process. The Leadership Council articulates legal and political advice from two non-governmental organisations with ties to the Catholic Church (CIMI and $\mathrm{CPT}$ ). Aided by these entities, they are able to make advances in their requests to other state agencies and international organs. During 2015 and 2016, these reports focused on land grabbing and the intensification of environmental devastation. Among the agencies contacted, the Secretary of State for Human Rights and Popular Participation (Secretaria de Estado dos Direitos Humanos e Participação Popular, SEDIHPOP) visited the territory on October $6^{\text {th }}$, 2015, attested to the veracity of facts alleged by the community, recommending that other organs responsible should take immediate action. The following is an excerpt from the descriptive report:

An extensive area has been devastated by bulldozers, in all likelihood, for the purpose of building weirs for the cultivation of fish (fish farming). In the devastated area, the Indians point to the existence of river springs, babaçu and juçara groves and sacred areas, that is, areas that have some kind of spiritual/religious reference for the group. These areas had been destroyed by the actions currently reported. We verified that an excessive amount of juçara palm trees and babaçu coconut palm trees have been torn down, thus harming the extraction of the babaçu coconut and juçara, respectively. (SEDIHPOP 2015:1)

The Gamella live off agriculture, gathering practices, fishing and the cultivation of babaçu coconut, therefore the nefarious consequences of these practices are twofold: one in relation to physical reproduction and the other of symbolic order. They are bound to the rivers and forest areas through their cosmologies; the Encantados are beings that dwell in these places and depend on them to exist and to communicate with the Indians during rituals.

Due to the spiritual importance of these areas, the Gamella no longer wait for the sluggish response of the authorities. The most effective actions are those taken by the communities, who formed human barricades to stop tractors from felling the trees. Women are the principal protagonists in these actions,

26 Compiled in case no. 08620.098509/2015-83, Vol.1, Ministry of Justice/National Indian Foundation, which deals with Gamella land claims. 
because the guarimãs and the babaçu palm trees are directly linked to the female universe. These actions of direct confrontation have the political support of an important social movement native to the state, the Babaçu Coconut Breakers' Movement (MQCB).

The actions of the Leadership Council are likewise oriented by collective organisation, aimed at access to indigenist policies ensured by the Brazilian Constitution. Among their claims is the creation of the Indigenous School ${ }^{27}$, with the perspective of formulating a cross-cultural syllabus based on specific knowledges that have been preserved and transmitted through oral history. Since education is fundamental to overcoming epistemic racism and the formation of subjectivities, the Municipal government of Viana not only refused to acknowledge requests for a specific school, at the beginning of the 2017 school year, but also closed the regular school that catered to children in primary school on the grounds of lack of resources. This act by the Secretary of Education is perceived by the Gamella as a strategy to make the collective project for education unfeasible and to maintain the people in a vulnerable situation regarding the hatred proliferating amid the local population. Gamella children are prevented from entering municipal schools when they are painted with urucum or jenipapo, as recalled by a Gamella mother: "they told my son he couldn't come to school looking dirty, that he should go home and clean himself up". The Inter-American Commission for Human Rights (Cidh) emphasises this point:

If that was not enough, the "hatred in relation to Indians" continues to be propagated in town, even by means of the radio programme referred to previously. At the local school, Gamella children are threatened by other children from the town: "Are you an Indian? My dad says he's gonna kill you all". This structure of insecurity is reinforced by the absence of specific public policies. (2017:29. Emphasis in the original).

Other forms of organisation are developed in articulations with social movements. The Gamella form important relationships with quilombola communities as well as the babaçu coconut breakers. This pluritechnical field mobilises networks of resistance and territorial defence both locally and regionally, with joint agendas decided on in specific forums, much like the movement called Teia dos Povose Comunidades Tradicionais do Maranhão [Web of Traditional Peoples and Communities in Maranhão], formed by communities, social movements, non-governmental organisations and scholars.

The Gamella's involvement in this space has provide the opportunity for a re-actualisation of hope after the violence. A little less than a month after the genocidal attack on April $30^{\text {th }}$, the Indians took part in the Sixth Meeting of the Web, which took place at the quilombola territory of Alto Bonito, from May $25^{\text {th }}$ to $27^{\text {th }}$ in 2017. The meeting's final document is a pact in favour of an agenda of territorial struggle, combat against agribusiness and the pursuit of Bem Viver [lit: good living] ${ }^{28}$ :

We, the indigenous peoples Akroá-Gamella, Krenyê, Krikati, Gavião, Krepym Katejê, Pataxó Hã Hã Hãe of Bahia, quilombola communities, coconut breakers, sertanejos, geraizeiros, artisanal fishermen, riparian peoples, peasants and rubber extractors from Acre $\left[. . .{ }^{29}\right.$ We denounce the development model that has been disseminated across Brazil, which is exploitative and concentrates wealth, and that must, in order to achieve

\footnotetext{
27 In Brazil, indigenous peoples were ensured the right to a bilingual and inter-cultural school education in the Constitution of 1988. From a formal standpoint, the indigenous and indigenist movements consider the current legislation to adequately address the greater majority of the peoples' aspirations; however, barriers can occur in the operationalisation of the right. The offer is decentralised for municipalities and states - in the Gamella's case, responsibility for offers falls on the Viana municipality. However, representatives with executive powers are among those involved in territorial disputes against the Indians. 28 Final document: “Não estamos extintos. Estamos de pé, em luta. Esta terra é nossa!" [We are not extinct. We stand, we struggle. This land is ours!] Available at: < https://www.miqcb.org/single-post/2017/05/31/Carta-final-do-VI-Encontr\% $33 \% \mathrm{~A}_{30}$-da-TEIA-de-Povos-e-Comunidades-Tradicionais-doMaranh\% $\mathrm{C}_{3} \% \mathrm{~A}_{3}$ >े. Accessed in December 2017.

$29[\ldots]$ with the solidarity and militant support of the Pastoral Land Commission (CPT), the Missionary Indigenist Counsel (CIMI), the Interstate Coconut Breakers Movement (MIQCB), the Sisters of Notre Dame, the Popular Peasant Movement (MCP), The Peoples' Network of Bahia, the Brejo Dioceses, The Centre for Studies, Research and Projects on Agrarian Reform (NERA), CSP-Conlutas, the Nódua Collective, the Açailândia Defence Centre, The Group for Development, Modernity and Environmental Studies (GEDMMA), The Centre for Geographical Studies (NEGO-UFMA), The Federal Institute for Education, Science and Technology (Pinheiro Campus), the Agroecology Network of Maranhão (RAMA).
} 
maximum natural exploitation, deny our existence, culture and ways of life, by violently taking part in the extermination of peoples and communities, like that which happened to the rural workers in Colniza, Mato Grosso, with the Akroá-Gamella people in Maranhão, and the rural workers of Pau D’árco in Pará. We reaffirm our struggle in standing up against agri-hydro-mining-business [...]. We reaffirm the principles of Bem Viver, which implies the retaking of our territories, of our autonomy. [...] Our strength is derived from the Encantados, it comes from our forefathers. [...] It is a strength that will never be silenced, that remains forever alive when we meet and feel one another. This land has owners! (Sepé Tiaraju).

Within the space of the Web, they build a political agenda of autonomy mirrored "casa adentro" [lit: inside the home; within], that is to say, based on knowledges native to the communities. This harkens back to a reflection of Fanon's (2010), when he states that the colonised individual, as they arrive at an understanding of themselves and begin to conceive the world in a distinct fashion, gives birth to hope, which imposes a setback on the colonial/racist universe.

\section{Final Considerations}

The Akroá-Gamella rebel against a historical experience of social hierarchisation, violence and oppression, to such an extent that we understand the "Movement for Peace" as a euphemism fabricated to mask an issue of genocide.

Since May 3oth, 2017, this people carry out a daily struggle for life (in all its representations) and transgress threats of death (in all its manifestations), because the violent acts analysed throughout this article are not conjectural; on the contrary, they are empirically observable in the practices and racist discourse that operates in this reality.

In view of this, the political insurgency of the Akroá-Gamella people develops as a project to confront their historical antagonists directed towards the retaking of their territory and the reversal of environmental damage caused in the last few decades. It has to do with the collective reflection on the intents, purposes and desires formulated in terms of community actions aimed at decolonising power relations.

Because it is a project, it demands the construction of strategic partnerships, the capacity for mobilisation among the people themselves, and the permanent exercise of addressing both the State and its agencies so they will return their territory and ensure collective safety, under the clear understanding that the State itself is one of the main violators of their rights.

Their organisational forms reinforce the power located in the community. It transgresses the principals of individualism, accumulation and private property. This point of view has been a way of living in disobedience to the principle of death that has pursued them throughout history and that still threatens them. Their traits point to the idea of a historical pluralism, that is, "it harkens back to the possibility that projects of continuity and reproduction of peoples may be oriented discordantly with the goals of capitalist, Eurocentric-racist modernity" (Segato 2012:15).

A plural history is a history that reflects the angle of those who are subjugated and who, despite the mechanisms of domination, in this context, exist as a people that asserts itself as a radical critique.

Received: September 30, 2017

Approved: January 06, 2018

Translated by: Philip Badiz 


\section{References}

ANDRADE, Maristela de Paula. 2008. Terra de Índio: identidade étnica e conflito em terras de uso comum. São Luís:Edufma.

APOLINÁRIO, Juciene Ricarte. 2005. Os Akroá e outros povos indígenas nas Fronteiras do Sertão-As práticas das políticas indígena e indigenistas no norte da capitania de Goiás-SeculoXVIII. Tese de Doutorado, Programa de Pós-Graduação em História -UFPE.

ARAÚJO, Helciane. 2010. Estado/Movimentos Sociais no campo: a trama da construção conjunta de uma política pública no Maranhão. Tese de Doutorado, Programa de Pós-Graduação em Sociologia - UFC.

ASSELIN, V. 2009. Grilagem: corrupção e violência em terras do Carajás. Imperatriz, MA: Ética.

BUTLER, Judith. 2017. Quadros de Guerra: quando a vida é passivel de luto? Rio de Janeiro:Civilização Brasileira.

CARNEIRO DA CUNHA, Manuela. 1987. Antropologia do Brasil. Mito, História, Etnicidade. São

Paulo:Brasiliense.

CASTRO-GOMEZ, Santiago. 2005. "Ciências sociais, violência epistêmica e o problema da invenção do outro". In: LANDER, Edgardo (Org.). A colonialidade do saber: eurocentrismo e ciências sociais. Perspectivas latino-americanas. Buenos Aires: CLACSO (Colección Sur Sur). pp 80-88.

COMISSÃO PASTORAL DA TERRA [CPT]. 2016. Conflitos no Campo Brasil. Goiania: Comissão Pastoral da Terra. Disponível em: < https://www.cptnacional.org.br >. Acesso em: nov.2017.

COMISSÃO INTERAMERICANA DE DIREITOS HUMANOS. 2017. A Situação de Direitos Humanos dos Povos Indígenas no Brasil- Informe dos Solicitantes. Audiência Pública, 23 de outubro de 2017. Montevidéu:CIDH. Disponível em: $<$ http://www.dpu.def.br/images/stories/pdf_noticias/2017/informe_cidh_indigenas.pdf $>$. Acesso em: nov.2017.

CONSELHO INDIGENISTA MISSIONÁRIO [CIMI]. 2017. Relatório de Violências contra os Povos Indígenas. Brasília: Conselho Indigenista Missionário. Disponível em: $<$ https:||www.cimi.org.br/>. Acesso em: ago.2017.

COSTA, Wagner Cabral da. 2006. “Do 'Maranhão Novo' ao 'Novo Tempo': trajetória da oligarquia Sarney no Maranhão". Observanordeste: FUNDAJ. Disponível em <http://www.fundaj.gov.br/geral/observanordeste/ cabral2.pdf $>$. Acesso em: set. 2017.

DANTAS, Beatriz Gois; SAMPAIO, José Augusto Laranjeiras; CARVALHO, Maria do Rosário de. 1992. "Os povos indígenas do nordeste brasileiro, um esboço histórico". In: CARNEIRO DA CUNHA (Org.). História dos Índios no Brasil. São Paulo: FAESP/SMC/Companhia das Letras. pp 431-456.

ESPINOSA, Monica. 2007. "Ese indiscreto asunto de la violencia. Modernidad, colonialidad y genocidio en Colombia”. In: CASTRO-GÓMEZ, Santiago; GROSFOGUEL, Ramon (Org.). El giro decolonial: reflexiones para una diversidad epistémica más allá del capitalismo global. Bogotá: Siglo del Hombre Editores; Universidad Central, Instituto de Estudios Sociales Contemporáneos e Pontificia Universidad Javeriana, Instituto Pensar. pp 267-288.

FANON, Frantz. 2008.Pele Negra, Máscaras Brancas. Salvador: Edufba.

FANON, Frantz. 2010. Os Condenados da Terra. Juiz de Fora: UFJF.

LITTLE, Paul. 2002. "Territórios Sociais e Povos Tradicionais no Brasil: por uma antropologia da territorialidade". Série Antropologia, n. 322, Brasília: UNB.

MARTINS, Marlúcia Bonifácio; OLIVEIRA, Tadeu Gomes de (Orgs.). 2011. Amazônia Maranhense: Diversidade e Conservação. Belém: MPEG.

MBEMBE, Achille. 2016. "Necropolítica”. Arte \& Ensaios, n. 32. Disponível em: <https:||revistas.ufrj.br/index. php/ae/article/view/8993/7169>. Acesso em: dez. 2017. 
OLIVEIRA, João Pacheco de. 1999. "Uma etnologia dos "índios misturados”? Situação colonial, territorialização e fluxos culturais". In: OLIVEIRA, João Pacheco de. (Org.). A viagem da volta: etnicidade, política e reelaboração cultural no Nordeste Indígena. Rio de Janeiro: Contracapa. pp 11-40.

OLIVEIRA, João Pacheco de. 2016. O nascimento do Brasil e outros ensaios: "pacificação", regime tutelar e formação de alteridades. Rio de Janeiro: Contra Capa.

QUIJANO, Anibal.2005. “Colonialidade do poder, eurocentrismo e América Latina”. In: LANDER, Edgardo (Org.). A colonialidade do saber: eurocentrismo e ciências sociais. Perspectivas latino-americanas. Buenos Aires: CLACSO (Colección Sur Sur). pp 107-130.

SECRETARIA DE ESTADO DOS DIREITOS HUMANOS E PARTICIPAÇÃO POPULAR. 2015. Relatório Descritivo de Visita:denúncia de crime ambiental no Território Indígena Gamela no município de Viana-MA. São Luís: SEDIHPOP.

SEGATO, Rita. 2012. "Gênero e colonialidade: em busca de chaves de leitura e de um vocabulário estratégico descolonial”. E-cadernos ces [Online], 18(2012):106-131.

\section{Caroline Leal}

Faculty of Anthropology of the University of International Integration of Afro-Brazilian Lusophony, Ceará, Brazil.

http://orcid.org/oooo-0001-6303-7984

E-mail: carolineleal@unilab.edu.br 